\title{
Analisis Pencarian Informasi Remaja Generasi z dalam Proses Pengambilan Keputusan Belanja Online (Analisis pada Mahasiswa Ilmu Komunikasi Universitas Tidar)
}

\author{
Fitria Khairum Nisa $^{1}$, Arief Bregas Viratama ${ }^{2}$, Nurul Hidayanti ${ }^{3}$ \\ Universitas Tidar, Magelang, Indonesia $1,2,3$ \\ fitriaknisa@untidar.ac.id ${ }^{1}$, bregasviratama@gmail.com², nhidayanti615@gmail.com ${ }^{3}$
}

\begin{abstract}
Abstrak
Berdasarkan survey, salah kegiatan berinternet yang paling sering dilakukan adalah belanja online sebanyak $44.6 \%$. Sedangkan generasi yang mendominasi penggunaan internet adalah generasi z. Generasi z merupakan generasi yang akrab dengan dunia digital dan berani mengambil resiko. Penelitian ini bertujuan untuk melihat bagaimana generasi z melakukan proses pencarian informasi dalam melakukan belanja online dengan menyebarkan angket serta melakukan wawancara mendalam. Penelitian ini menggunakan mix method. Adapun subjek dari penelitian ini adalah mahasiswa Program Studi Ilmu Komunikasi, Universitas Tidar. Hasil penelitian ini menunjukan bahwa ulasan produk di e-commerce merupakan sumber utama remaja generasi z dalam mencari informasi yakni sebesar $80.7 \%$. Sumber informasi lainnya adalah ulasan produk di sosial media dan bertanya kepada teman. Adapun alasannya adalah untuk mencari trend terkini serta ulasan produk dapat dipercaya dan generasi z peduli dengan pendapat orang sekitar.
\end{abstract}

Kata kunci: Generasi z, Pencarian informasi, Keputusan belanja online

\begin{abstract}
Based on the survey, one of the most frequently carried out internet activities was online shopping which is $44.6 \%$. Meanwhile, the generation that dominates internet usage is $z$ generation. $Z$ generation $z$ is a generation that is familiar with the digital world and is willing to take risks. This study aims to see how generation $Z$ performs the information search process in online shopping. This study uses a mix method by distributing questionnaires and conducting in-depth interviews. Subject of this research is the students of communication in Tidar University. The results of this study indicate that product reviews on e-commerce is the main source of $z$ generation adolescents in seeking information, which is $80.7 \%$. Other sources of information are product reviews on social media and asking friends. The reasons for those are they look for the newest trend and product reviews are trustworthy and z generation cares what people think about them.
\end{abstract}

Keywords: z generation, information search, online buying decision 


\section{PENDAHULUAN}

Peningkatan penggunaan internet pada tahun 2020 dipengaruhi oleh pandemi COVID-19 yang melanda hampir seluruh negara. Berdasarkan data dari We Are Sosial pada Juli 2020 penggunaan internet di dunia mengalami peningkatan sebesar $8.2 \%$ jika dibandingkan pada tahun sebelumnya. Berdasarkan hasil survey yang sama, sebanyak 83\% orang-orang menggunakan internet karena lockdown yang harus dijalani. Di Indonesia sendiri, pengguna internet phingga Januari 2020 sebanyak 175.4 juta pengguna. Jika dibandingakan dengan tahun sebelumnya, terdapat peningkatan sebesar $17 \%^{1}$.

Adapun pengguna internet di Indonesia didominasi oleh generasi $\mathrm{z}$ baru kemudian diikuti dengan generasi $\mathrm{X}$, generasi $\mathrm{Y}$ dan terakhir generasi baby boomers. Sedangkan beberapa kegiatan yang dilakukan menggunaan jejaring internet selama pandemi COVID-19 antara lain bertukar pesan, berselancar di dunia maya, mengakses jejaring sosial (70,\%), menonton video tanpa unduh atau video streaming, mengirim e-mail, mengunduh dan belanja online $^{2}$. Berdasarkan hasil survei dari Alvara Research Center, kegiatan belanja online, mencapai $44.6 \%$ atau terbanyak ke-6. Namun secara global, Indonesia menempati urutan pertama dalam kegiatan belanja online melalui e-commerce pada Juli 2020 (usia 16-64 tahun $)^{3}$.

Beberapa penelitian tentang generasi $\mathrm{z}$ dan belanja online menunjukan gaya berlanja online generasi z yang cukup unik. Santoso dan Triwijayati menyebutkan bahwa generasi z di Indonesia tidak terlalu peduli harga pakaian yang akan dibeli dan kurang sensitif dengan harga. Selain itu juga brand consciousness dari generasi z cukup tinggi, dimana mereka sangat mempertimbangkan pembelian pakaian dengan brand yang cukup terkenal walaupun harus membeli dengan harga yang lebih mahal. Konsumen generasi z cenderung tidak sensitif harga, mempertimbangkan merek produk, hedonis dan impulsif ${ }^{4}$. Penelitian lain yang dilakukan oleh Hidvégi dan Kelemen-Erdős menunjukan bahwa generasi z menggunakan internet sebagai sumber utama dalam mencari infomasi namun di sisi lain juga

\footnotetext{
${ }^{1}$ We Are Sosial. (2020). Digital 2020: July Global Statshot Report. Diakses dari https://datareportal.com/reports/digital-2020-july-global-statshot

${ }^{2}$ Ibid

3 Bisnis.com. (2020). Survei Alvara: Puncak Aktivitas Internet Masyarakat Pukul 8 Malam. Diakses dari https://teknologi.bisnis.com/read/20200712/101/1264941/survei-alvara-puncak-aktivitas-internetmasyarakat-pukul-8-malam

${ }^{4}$ Giovani Santoso dan Anna Triwijayati, Anna. (2018). "Gaya Pengambilan Keputusan Pembelian Pakaian Secara Online pada Generasi z Indonesia”. Jurnal Ilmu Keluarga dan Konsumen. Institut Pertanian Bogor. Vol. 11(3) hal. 239.
} 
mempertimbangkan pendapat dari teman dan keluarga dalam mengambil keputusan ${ }^{5}$. Hal ini juga terlihat pada penelitian dari Ramadhan dan Simanjuntak yang menyatakan bahwa generasi z peduli dengan kelompok acuan ${ }^{6}$.

Hal ini menjadi menarik untuk diteliti, meskipun generasi $\mathrm{z}$ terlihat berani dalam melakukan pembelian online, serta akrab dengan dunia digital, tetapi generasi $\mathrm{z}$ memilih membutuhkan saran, pendapat dan masukan dari orang lain, seperti keluarga dan teman. Mereka tidak sepenuhnya mengandalkan pencarian atau rekemomendasi melalui internet. Hal bertolak belakang dengan remaja pada generasi sebelumnya atau generasi milenial. Penelitian oleh Ketto dan Murti menunjukkan bahwa remaja menggunakan media sosial sebagai sumber pencarian informasi utama seperti Twitter dan FaceBook, baru kemudian bertanya kepada teman atau keluarga ${ }^{7}$. Perilaku tersebut memiliki persamaan dengan generasi $\mathrm{Y}$, dimana mereka lebih mempercayai teman ketika mencari informasi suatu produk untuk belanja online $^{8}$ (Azizah \& Februadi, 2019:794). Oleh karena itu penelitian ini ingin mencari tahu bagaimana generasi z melakukan proses pencarian informasi dalam melakukan belanja online serta sumber utama apa yang digunakan ketika mencari informasi tersebut.

\section{TINJAUAN PUSTAKA}

\section{Generasi $z$}

Menurut McCrindle generasi z merupakan generasi yang lahir sejak tahun 1995 hingga 2009. Usia generasi z pada tahun 2020 adalah sekita 11- 25 tahun $^{9}$. Generasi z juga dikenal dengan sebutan Generasi Net atau Generasi internet. Hal ini dikarena generasi tersebut lahir saat internet mulai masuk dan berkembang secara pesat dalam kehidupan ${ }^{10}$. Menurut David Stillman dan Johan Stillman, generasi $\mathrm{z}$ memiliki 7 (tujuh) sifat atau karakter $^{11}$, yaitu:

\footnotetext{
${ }^{5}$ Anna Hidvégi dan Anikó Kelemen-Erdős. (2016). Assessing the Online Purchasing Decisions of Generation Z. FIKUSZ '16 Symposium for Young Researchers. Óbuda University. hal. 180

${ }^{6}$ Andre Fachrun Ramadhan dan Megawati Simanjuntak. (2018). Perilaku Pembelian Hedonis Generasi z: Promosi Pemasaran, Kelompok Acuan, Dan Konsep Diri. Jurnal Ilmu Keluarga dan Konsumen. Institut Pertanian Bogor. Vol. 11(3) hal. 252

${ }^{7}$ Paskalis Ferdinan Bereket Ketto \& Desideria Cempaka Wijaya Murti. (2014). Proses Pengambilan Keputusan dalam Membeli Sepatu Olahraga. Jurnal Ilmu Komunikasi. Universitas Atma Jaya Yogyakarta, hal 4

${ }^{8}$ Sabila Hanifan Azizah \& Agustinus C. Februadi. (2019). Motivasi Belanja Fesyen Online: Perspektif Generasi Y Wanita. $10^{\text {th }}$ Industrial Research Workshop and National Seminar. Universitas Padjajaran. Hal. 794

${ }^{9}$ Mark McCrindle. (2009). The ABC of XYZ: Understanding the global generations. Bella Vista: McCrindle Research Pty. Hal. 12

${ }^{10}$ Don Tapscott. (2009). Grown Up Digital: How the Net Generation is Changing Your World. New York: McGraw Hill. Hal. 15

${ }^{11}$ David Stillman dan Jonah Stillman. (2017). Gen Z Work: How the Next Generation Is Transforming the Workplace. New York: HarperCollins Publishers.
} 
1. Phigital: generasi z merupakan generasi yang terlahir di mana kehidupan fisik atau dunia nyata dan dunia virtual sejajar. Sehingga mereka sudah terbiasa berada di kedua dunia tersebut.

2. Hyper-custom: generasi z senang memodifikasi atau mengubah barang yang dimilikinya, hal tersebut mencerminkan bahwa generasi tersebut menunjukan identitas pada dirinya yaitu kebebasan berekspresi.

3. Realistic: generasi $\mathrm{z}$ memiliki cita-cita yang tinggi akan tetapi generasi $\mathrm{z}$ juga tetap memikirkan realistis yang ada pada dunia nyata.

4. FOMO (Fear of Missing Out): generasi z memiliki ketakukan akan ketertinggalan. Generasi ini sangat update pada lingkungan yang ada disekitar mereka, seperti pemberitaan yang ada di media sosial.

5. Weconomists: sharing ekonomi merupakan salah satu hal yang biasa terjadi pada generasi ini, sharing ekonomi merupakan bisnis yang menyediakan akses kepada sumber daya yang dimiliki orang lain atau perusahaan agar dapat dikonsumsi bersaman, seperti grab, gojek dan lain-lain.

6. DIY (Do it Yourself): sebagai generasi yang hadir pada dunia teknologi, mereka tumbuh bersama dengan sosial media, salah satunya YouTube. Dengan demikian, mereka dapat memperoleh banyak informasi mengenai berbagai cara melakukan apapun. Sehingga generasi z merasa mereka dapat melakukan apapun sendiri.

7. Driven: generasi $\mathrm{z}$ memiliki jiwa kompetitif atau kompotisi kepada mereka yang melakukan pekerjaan yang sama, hal tersebut dapat membuat seseorang terus terpacu untuk melakukan hal yang sebaik mungkin.

Berdasarkan hasil penelitian oleh Hidvégi dan Kelemen-Erdős, generasi z memulai dengan keuntungan besar dibandingkan generasi lain di dunia digital ini: mereka dapat mengumpulkan informasi dengan sangat cepat, mereka beradaptasi dengan baik, mereka dapat melakukan banyak tugas, mereka menghabiskan banyak waktu luang mereka untuk berselancar web, dan hampir selalu tersedia secara online ${ }^{12}$. Wijoyo dkk juga menyebutkan bahwa generasi z sangat intens berinteraksi melalui media sosial dengan semua kalangan, khususnya dengan teman sebaya melalui media sosial ${ }^{13}$.

\footnotetext{
${ }^{12}$ Anna Hidvégi dan Anikó Kelemen-Erdős. (2016). Assessing the Online Purchasing Decisions of Generation Z. FIKUSZ '16 Symposium for Young Researchers. Óbuda University. hal. 179

${ }^{13}$ Wijoyo, Hadion dkk. (2020). Generasi z dan Revolusi Industri 4.0. Banyumas: CV. Pena Persada. Hal. 1
} 


\section{Pencarian Informasi dalam Pengambilan Keputusan Belanja Online}

Keputusan pembelian menurut Kotler dan Keller (2012:166) merupakan tahap dalam proses pengambilan keputusan pembeli di mana konsumen benar-benar membeli. Konsumen biasanya melewati lima tahap: pengenalan masalah, pencarian informasi, evaluasi alternatif, keputusan pembelian, dan perilaku pascapembelian. Proses pembelian dimulai jauh sebelum pembelian sebenarnya dan memiliki konsekuensi lama setelahnya. Meski demikian, konsumen tidak selalu melewati kelima tahap tersebut. Mereka bisa melewati salah satu proses atau mengulang ${ }^{14}$. Pada penelitian ini, peneliti fokus melihat pada tahap pencarian informasi generasi z dalam proses pengambilan keputusan pembelian secara online.

Pada tingkat ini seseorang menjadi lebih menerima informasi tentang suatu produk. Ketika fase pengenalan masalah telah terpenuhi, konsumen akan mulai mencari tahu informasi yang berkaitan dengan barang yang ingin mereka beli. Informasi ini berasal dari sumber yang beragam, mulai dari testimoni pelanggan, bertanya kepada kolega yang memiliki pengalaman atau mempunyai barang yang akan dibeli, mengunjungi toko, dan lain sebagainya. Kotler dan Keller menilai terdapat empat jenis sumber informasi konsumen ${ }^{15}$, yaitu:

1. Sumber pribadi: sumber pribadi adalah ketika seseorang mencari informasi melalui orang-orang yang berada di sekitar mereka sebelum membuat keputusan belanja. Di antaranya keluarga, teman, pasangan, tetangga dan sebagainya.

2. Sumber komersial: sumber komersial di antaranya iklan, sales person, distributor, kemasan, pajangan ditoko.

3. Sumber publik: sumber publik merupakan informasi yang diberikan oleh masyarakat luas, biasanya melalui ulasan produk. Ulasan ini bisa disampaikan melalui beberapa media seperti sosial media, forum atau platform belanja.

4. Sumber pengalaman: pengalaman merupakan pencarian infomasi dengan melihat, mnelaah atau mencoba langsung produk sebelum memutuskan untuk membeli.

\section{METODE PENELITIAN}

Penelitian ini menggunakan menggunakan mix method antara metode kuantitatif dan kualitatif. Hal ini dilakukan untuk mendapatkan gambaran yang menyeluruh sekaligus mendalam terkait proses pencarian informasi generasi $\mathrm{z}$ dalam melakukan belanja online.

\footnotetext{
${ }^{14}$ Philip Kotler dan Kevin Lane Keller. (2012). Marketing Management: $14^{\text {th }}$ Edition. New Jersey: Pearson Education. Hal. 166 15 Ibid.
} 
Adapun populasi dari penelitian ini adalah mahasiswa Program Studi Ilmu Komunikasi, Universitas Tidar angkatan 2017-2019 dengan rentang usia 18-22 tahun. Berdasarkan populasi tersebut, sampel yang didapat sebanyak 133 responden. Adapun teknik pengambilan sampel yang dilakukan adalah sampling insidental dengan pertimbangan lokasi responden yang cukup menyebar, sehingga peneliti hanya memiliki responden yang dapat dijangkau.

Secara kuantitatif, peneliti menyebarkan angket kepada responden. Sedangkan secara kualitatif peneliti melakukan wawancara mendaam kepada beberapa responden berdasarkan hasil dari angket yang diberikan. Adapun responden yang diwawancarai yang memiliki salah satu kriteria yang ditentukan: 1. Responden yang memiliki hasil angket dengan kecenderungan sesuai dengan jawaban mayoritas responden, 2. Responden yang memiliki hasil angket dengan kecenderungan bertolak belakang dengan jawaban mayoritas responden. Berdasarkan kriteria tersebut terdapat 8 responden yang diwawancari.

Teknik analisis data yang digunakan dalam penelitian ini adalah analisis univariat yang menghasilkan distribusi frekuensi dan prosentase tiap variabel pencarian informasi oleh Kotler, yakni sumber pribadi, komersial, publik dan pengalaman. Kemudian setelah didapatkan hasil prosentase, peneliti melakukan wawancara dan melakukan coding berdasarkan hasil wawancara dengan responden tersebut.

\section{HASIL DAN DISKUSI}

Berdasarkan hasil survey terdapat 133 responden yang terbagi menjadi 82 responden perempuan dan 51 responden laki-laki dengan persebaran usia sebagai berikut:

Tabel 1.

Sebaran Usia Responden

\begin{tabular}{c|c}
\hline Usia & Jumlah \\
\hline 18 & 8 \\
19 & 51 \\
20 & 47 \\
21 & 17 \\
22 & 10 \\
\hline Jumlah & 133 \\
\hline
\end{tabular}

Penelitian ini fokus pada tiga jenis produk yang sering dibeli secara online, yakni sandang (pakaian dan sepatu) sebanyak 70.3\%, aksesoris (perhiasan, tas, ikat pinggang, kacamata, dsb) sebanyak 56\% dan perlengkapan hobi sebanyak $48.4 \%$.

Gambaran lainnya adalah platform belanja online yang sering digunakan adalah melalui e-commerce yakni sebesar 87.2\%, kemudian media sosial (Instagram, twitter, facebook, dsb) sebesar $25.6 \%$, website resmi sebesar $10.5 \%$. 
Adapun faktor yang menyebabkan platfom e-commerce lebih banyak digunakan adalah karena keamanannya, di mana, responden sebagai pembeli merasa terlindungi dari penipuan, kemudian kemudahannya mencari segala jenis barang, serta banyak program penawaran seperti promo, diskon, gratis ongkos kirim dan sebagainya yang bisa menguntungkan responden. Alasan lainnya, beberapa response pernah tertipu ketika melakukan belanja online melalui media sosial Instagram dan Facebook. Sehingga mereka tidak percaya lagi untuk melakukan belanja online di platform tersebut. Namun, jika yang menjual barang adalah orang yang sudah dikenal, mereka akan bersedia untuk melakukan pembelian melalui media sosial.

\section{Pencarian Informasi dalam Pengambilan Keputusan Belanja Online}

1. Sumber Pribadi

Sumber pribadi dalam penelitian ini dikelompokkan menjadi tiga bagian, yakni keluarga, teman dan orang lain (selain keluarga dan teman). Kelompok orang lain yang dimaksud adalah pasangan, tetangga atau kenalan.

Tabel 2.

Pencarian Sumber Pribadi

\begin{tabular}{l|ccc}
\hline $\begin{array}{l}\text { Sumber } \\
\text { informasi }\end{array}$ & Tidak pernah & Jarang & Selalu \\
\hline Keluarga & $40.36 \%$ & $42.1 \%$ & $17.53 \%$ \\
Teman & $24.57 \%$ & $60.67 \%$ & $14.76 \%$ \\
Orang lain & $51.13 \%$ & $38.1 \%$ & $10.17 \%$
\end{tabular}

Berdasarkan hasil survey tersebut, telihat bahwa hanya sebanyak $17.53 \%$ remaja generasi z yang mencari selalu informasi pada keluarga sebelum belanja online. Mereka cenderung jarang bahkan tidak pernah mencari informasi kepada keluaga. Sedangkan pencarian informasi kepada teman jarang dilakukan, yakni sebanyak 60.67\%. Terakhir pencarian informasi melalui orang lain cenderung tidak pernah dilakukan, yakni sebesar $51.13 \%$.

Berdasarkan hasil wawancara dengan beberapa responden, beberapa penyebab mereka jarang mencari informasi melalui keluarga adalah karena merasa apa yang dibeli merupakan selera dan keinginan pribadi sehingga tidak perlu ditanyakan kepada keluarga, kemudian ada juga responden yang menyebutkan bahwa uang yang digunakan adalah uang pribadi sehingga tidak perlu mencari informasi melalui keluarga. Namun demikian, komunikasi dengan keluarga sebelum membeli barang secara online juga dilakukan jika anggota keluarga mereka memiliki pengalaman menggunakan produk yang dingin dibeli. 
Selain itu, komunikasi yang dilakukan hanya sebatas meminta izin, terutama jika barang tersebut dibelikan oleh keluarga.

Pencarian informasi kepada teman lebih kepada informasi mengenai produk yang akan dibeli. Adapun faktor yang menyebabkan hal tersebut adalah teman mereka memiliki pengalaman dan lebih paham tentang produk yang akan dibeli, atau ingin mendengar pendapat teman-teman apakah barang yang akan dibeli sesuai dengan mereka. Namun memang tidak selalu dilakukan, hal ini disebabkan karena mereka merasa apa yang akan dibeli merupakan selera sendiri sehingga tidak perlu ditanyakan kepada orang lain.

Sedangkan infomasi kepada orang lain, diantaranya adalah kepada pasangan dan tetangga. Responden yang mencari informasi kepada pasangan lebih mencari informasi tentang kecocokan produk dengan dirinya, terutama ketika membeli pakaian. Sedangkan salah satu informan yang menyebutkan tetangga, karena orang tersebut mengerti tentang produk yang akan dibeli.

\section{Sumber Komersial}

Sumber komersial dalam penelitian ini dibedakan menjadi tiga, yakni iklan, website resmi dan sales person.

Tabel 3.

Pencarian Sumber Komersial

\begin{tabular}{l|ccc}
\hline & Tidak pernah & Jarang & Selalu \\
& & & \\
\hline Iklan & $13.3 \%$ & $51.13 \%$ & $35.57 \%$ \\
Website & $11.76 \%$ & $44.87 \%$ & $43.37 \%$ \\
Sales & $24.3 \%$ & $47.37 \%$ & $28.33 \%$ \\
\hline
\end{tabular}

Berdasarkan hasil survey pencarian informasi melalui sumber komersial, terlihat bahwa responden jarang mencari informasi melalui ketiga sumber, iklan website, dan sales. Meski demikian, pencarian informasi tersebut juga pernah dilakukan dengan berberapa alasan. Pencarian informasi melalui iklan dilakukan untuk melihat tren yang ada saat ini. Adapun iklan yang dimaksud adalah iklan yang muncul di sosial media responden.

Pencarian informasi melalui website dilakukan untuk melihat informasi lengkap tentang produk yang dibeli, seperti spesifikasi, harga, dan informasi detil tentang produk. Cenderung dilakukan ketika mencari informasi tentang produk elektronik. Hal ini dilakukan karena website resmi memiliki informasi yang akurat, bisa dipercaya dan cukup lengkap. Sedangkan pencarian informasi melalui sales person, dilakukan guna 
mendapatkan informasi tentang ketersediaan barang atau informasi lain selain produk. Seperti proses pengiriman dan sebagainya.

3. Sumber Publik

Pada penelitian ini sumber informasi dari publik diambil dari sosial media diantaranya Instagram, YouTube, TikTok, dan Facebook. Keempat media sosial tersebut dipilih karena merupakan sosial media yang paling banyak digunakan oleh responden. Sedangkan blog dan ratting/ulasan merupakan sumber lain yang peneliti anggap merupakan sumber publik.

Tabel 4.

Pencarian Sumber Publik

\begin{tabular}{l|ccc}
\hline Media & Tidak pernah & Jarang & Selalu \\
& & & \\
\hline Instagram & $10.53 \%$ & $42.57 \%$ & $46.9 \%$ \\
YouTube & $20.33 \%$ & $33.83 \%$ & $45.84 \%$ \\
TikTok & $72.67 \%$ & $22.07 \%$ & $5.26 \%$ \\
Facebook & $69.67 \%$ & $25.57 \%$ & $4.76 \%$ \\
Blog/Forum & $28.07 \%$ & $51.63 \%$ & $20.3 \%$ \\
Ratting/Ulasan & $5.53 \%$ & $13.77 \%$ & $80.7 \%$ \\
\hline
\end{tabular}

Hasil survey menunjukkan bahwa sumber informasi dari publik yang cenderung selalu digunkaan adalah ratting produk, yakni sebesar $80.7 \%$. Sedangkan media sosial yang cenderung tidak pernah digunakan untuk mencari informasi sebelum belanja online adalah TikTok.

Berdasarkan hasil wawancara, Instagram cenderung jarang hingga sering digunakan untuk mencari informasi sebelum belanja online karena untuk menjadi bahan referensi sebelum membeli. Referensi trend terkini serta visual dari produk yang dijual. Biasanya produk yang sering dilihat adalah sandang. Sedangkan YouTube juga cenderung sering digunakan untuk mencari informasi dengan alasan medianya yang bersifat audio-visual sehingga penjelasan tentang produk lebih detil dan lebih mudah untuk dipahami. Adapun informasi yang sering dicari adalah informasi mengenai produk itu sendiri. Seperti spesifikasi barang elektronik atau ulasan tentang peroduk kencantikan.

TikTok cenderung tidak pernah digunakan untuk mencari informasi sebelum belanja online, tetapi salah satu responden yang selalu menggunakan TikTok sebagai sumber informasi menyebutkan bahwa ulasan yang ada di TikTok lebih bisa dipercaya karena individu yang memberikan ulasan hanya konsumen biasa (bukan dibayar untuk mengulas) sehingga informasinya lebih bisa dipercaya. Serupa dengan TikTok, Facebook juga cenderung tidak pernah digunakan untuk mencari informasi. Hal ini karena meskipun 
remaja generasi z masih memiliki akun Facebook, namun media sosial tersebut sudah jarang digunakan. Salah satu responden menyebutkan, bahwa ia menggunakan Facebook ketika diminta oleh orang tuanya untuk mencari informasi tentang suatu produk.

Blog atau forum diskusi juga cenderung jarang digunakan. Respoonden menggunakan blog atau forum diskusi ketika memerlukan informasi yang lengkap dari pengguna produk, kemudian bisa berkomunikasi langsung dengan pemberi ulasan. Sedangkan ratting dan ulasan di platform belanja cenderung selalu digunakan. Adapun informasi yang dicari adalah tentang kualitas produk serta penjual. Menurut responden, ulasan tersebut dapat memperlihatkan reputasi dari penjual, bisa dipercaya, serta gambaran produk yang dijual lebih realistik. Berdasarkan seluruh responden yang diwaawancarai, mereka akan selalu melihat ratting dan ulasan ketika belanja online di $e$ commerce meskipun sudah meminta pendapat dari orang lain atau sumber informasi lain. Hal ini untuk memantapkan dirinya untuk mengambil keputusan pembelian secara online.

4. Sumber Pengalaman

Sumber pengalaman pada penelitian ini adalah ketika responden mencoba langsung produk yang akan dibeli. Percobaan tersebut dilakukan dengan mendatangi toko atau mencoba produk yang sudah dimiliki oleh orang di sekitar mereka.

Tabel 5.

Pencarian Sumber Pengalaman

\begin{tabular}{l|lll}
\hline & $\begin{array}{r}\text { Tidak } \\
\text { pernah }\end{array}$ & Jarang & Selalu \\
& & & \\
\hline Pengalaman & $25.83 \%$ & $56.63 \%$ & $17.54 \%$ \\
\hline
\end{tabular}

Pencarian informasi melalui sumber pengalaman cenderung jarang dilakukan. Berdasarkan wawancara dengan beberapa responden, alasannya karena informasi yang mereka butuhkan sudah terpenuhi dari sumber-sumber lain. Namun di sisi lain, mereka biasanya tidak sengaja mencoba produk yang ingin dibeli dengan cara mencoba punya teman atau keluarga tanpa ada niatan untuk membeli. Tetapi hal yang sama juga pernah dilakukan dua orang responden yang diwawancarai. Keduanya menyebutkan bahwa sengaja untuk datang ke toko untuk mencoba produk yang ingin dibeli. Hal ini berhubungan dengan ukuran dari produk yang akan dibeli, misalnya sepatu dan pakaian. Namun mereka akan tetap beli secara online karena harganya yang lebih murah.

Berdasarkan hasil temuan, terlihat bahwa sumber utama pencarian informasi remaja generasi z sebelum mengambil keputusan melakukan pembelian secara online adalah melalui sumber publik. Kotler menyebutkan bahwa sumber publik adalah informasi yang diberikan 
oleh masyarakat umum melalui media sosial. Ini menunjukkan bahwa remaja generasi z lebih percaya dengan ulasan yang diberikan oleh publik. Meski iklan produk yang ditampilkan sangat menarik, mereka tetap realistis untuk selalu melihat produk asli yang dijual melalui ulasan konsumen lain. Sesuai dengan karakteristik genereasi z yang realistis.

Penelitian dari Kamila dkk menunjukan bahwa ulasan produk merupakan pengaruh yang paling kuat terhadap keputusan pembelian oleh remaja ${ }^{16}$. Sejalan dengan hasil penelitian ini, di mana ulasan produk menjadi sumber informasi utama sebelum melakukan belanaja online oleh remaja di generasi z. Penelitian yang sama sebelumnya oleh Kardon menjelaskan bahwa konsumen lebih bergantung pada peer review daripada informasi yang disajikan oleh entitas bisnis karena pendapat sesama konsumen lebih dinilai tidak memihak dan lebih terpercaya ${ }^{17}$. Selian itu pendapat pribadi dan pengalaman atas penggunaan produk dan jasa dalam bentuk review di internet menjadi salah satu sumber informasi yang paling bernilai untuk membantu pengguna (user) ketika membuat proses keputusan pembelian ${ }^{18}$.

Media sosial seperti Instagram juga tidak hanya digunakan oleh remaja generasi z untuk melihat ulasan tentang produk yang dibeli tetapi juga untuk mencari informasi tentang trend terbaru. Mereka mengikuti akun orang atau merek tertentu di Instagram untuk melihat fashion, makeup, dan style terkini. Untuk kemudian mereka mempunyai gambaran produk seperti apa yang sebaiknya mereka beli. Hal ini menggambarkan sifat dari generasi z yakni FOMO atau fear of missing out. Mereka selalu ingin update dengan keadaan sekitar dan tidak ingin tertinggal. Selain itu, gambaran ini juga sesuai dengan karakteristik generasi z yang akrab dengan dunia digital. Mereka bisa dengan mudah mendapatkan informasi melalui platform digital seperti forum diskusi, media sosial, platform jual beli online dan sebagainya. Seperti yang disebutkan oleh Hidvégi dan Kelemen-Erdős bahwa generasi z sangat mudah dan cepat dalam mencari informasi ${ }^{19}$.

Meski demikian, di sisi lain remaja generasi $\mathrm{z}$ juga peduli akan pendapat orang sekitarnya, terutama teman dan pasangan. Mereka jarang mencari informasi melalui keluarga ketika melakukan belanja online. Komunikasi yang terbentuk antara mereka dan keluarga

16 Korina Tasya Kamila dkk. (2019). Pengaruh Online Consumer Review terhadap Keputusan Pembelian (Survei Pada Mahasiswa Universitas Brawijaya Ta 2015/2016 - 2018/2019 Yang Pernah Membeli Dan Menggunakan Xiaomi Smartphone). Jurnal Administrasi Bisnis. Universitas Brawijaya. Vol.7(01) hal. 210

${ }^{17}$ B Kardon. (2007), They're saying nasty things. Marketing News, Vol. 41(20), hal. 30

18 A. Y. Chua \& S. Banerjee. (2015). Understanding Review Helpfulness as a Function of Reviewer Reputation, Review Rating, and Review Depth. Journal of the Association for Information Science \& Technology, vol. 66(2), hal. 359.

${ }^{19}$ Anna Hidvégi dan Anikó Kelemen-Erdős. (2016). Assessing the Online Purchasing Decisions of Generation Z. FIKUSZ '16 Symposium for Young Researchers. Óbuda University. hal. 179 
hanya sebatas izin untuk melakukan belanja online khususnya kepada orang tua mereka. Sedangkan pencarian informasi melalui teman dan pasangan, hampir selalu dilakukan. Remaja generasi z merasa teman dan pasangan memiliki pendapat yang objektif, lebih paham tentang produk yang akan mereka beli. Namun di sisi lain, informasi yang kerap ditanyakan kepada teman dan pasangan adalah tetang kecocokan produk yang akan dibeli dengan dirinya. Hal ini menunjukkan bahwa remaja generasi z peduli dengan pendapat orang sekitar. Terutama bagi mereka yang memiliki pasangan. Pasangan merupakan sumber pencarian informasi utama. Mereka cenderung mengambil tindakan yang disetujui oleh pasangannya. Hal ini juga terjadi ketika mereka mencari informasi melalui teman.

Dalam hal ini teman dan pasangan dari remaja generasi z merupakan kelompok acuan mereka. Menurut Yang dkk terdapat pengaruh yang signifikan kelompok referensi terhadap pemilihan produk ${ }^{20}$. Pengaruh kelompok referensi pada konsumen sangat kuat menjadikan konsumen memiliki kriteria khusus saat dihadapkan keputusan pembelian produk. Pendapat yang sama juga dibuktikan oleh Dian dan Artanti, dalam penelitiannya menunjukkan bahwa kelompok acuan mempunyai pengaruh yang kuat pada konsumen dalam mengevaluasi suatu produk dan berujung pada keputusan pembelian ${ }^{21}$. Adanya kelompok acuan juga dapat membuat konsumen tidak memperdulikan harga pada produk karena adanya kriteria khusus yang ditancapkan pada pemikiran konsumen tersebut. Hasil penelitian yang sama juga diungkapkan oleh Pramudi yang mengatakan bahwa kelompok acuan atau kelompok referensi merupakan salah satu faktor yang memengaruhi seseorang untuk melakukan pembelian ${ }^{22}$. Sehingga sangat relevan jika dikatakan bahwa salah satu pencarian informasi utama oleh remaja adalah sumber pribadi.

\section{KESIMPULAN}

Dalam pencarian informasi sebelum melakukan belanja secara online, remaja generasi z melakukan beberapa kegiatan utama. Diantaranya, mencari informasi melalui sumber publik, seperti melihat ulasan produk di media sosial atau patform belanja online karena pendapat konsumen lain lebih dapat dipercaya. Selain itu, pencarian informasi melalui media

\footnotetext{
${ }^{20}$ Yang, Jiaqin dkk. (2007). Social Reference Group Influence on Mobile Phone Purchasing Behavior: A Aross Nation Comparative study". Journal Mobile Communications. InderScience Publishers. Vol. 5(3) hal. 319338.

${ }^{21}$ Dian, N. F., dan Artanti, Y. (2013). Pengaruh Kelompok Acuan dan Atmosfir Restoran Terhadap Keputusan Pembelian Konsumen Starbucks Coffee. Jurnal Ilmu Manajemen. Universitas Negeri Surabaya. Vol. 1(2), hal. 421.

22 Pramudi, R. Y. (2015). Pengaruh gaya hidup konsumtif dan kelompok referensi terhadap keputusan pembelian kosmetik lokal. Jurnal Riset Ekonomi dan Manajemen, 15(2), hal. 293
} 
sosial juga ditujukan untuk mencari informasi trend terkini, sehingga mereka memiliki gambaran tentang produk apa yang sebaiknya mereka beli. Di lain sisi, meski mereka akrab dengan dunia digital dan mempercayai ulasan dari konsumen lain di platform digital, remaja generasi z juga peduli dengan pendapat orang sekitar mereka, seperti teman dan pasangan sebagai kelompok acuan mereka. Remaja generasi $\mathrm{z}$ akan bertanya kepada teman dan pasangan ketika berkaitan dengan tampilan mereka. Apakah produk tersebut cocok untuk mereka. Mereka merasa nyaman untuk bertanya kepada teman-teman mereka karena dirasa akan memberikan pendapat yang objektif. Selain itu, bertanya kepada teman dianggap bahwa mereka memiliki pemahaman yang lebih tentang produk yang akan dibeli.

\section{DAFTAR PUSTAKA}

Azizah, Sabila Hanifan dan Februadi, Agustinus C. (2019). Motivasi Belanja Fesyen Online: Perspektif Generasi Y Wanita. 10 $0^{\text {th }}$ Industrial Research Workshop and National Seminar. Universitas Padjajaran. Hal. 789-799

Bisnis.com. (2020, Juli 12). Survei Alvara: Puncak Aktivitas internet Masayarakat Pukul 8 Malam. Bisnis.com.

https://teknologi.bisnis.com/read/20200712/101/1264941/survei-alvarapuncak-aktivitas-internet-masyarakat-pukul-8-malam

Chua, A. Y., \& Banerjee, S. (2015). Understanding Review Helpfulness as a Function of Reviewer Reputation, Review Rating, and Review Depth. Journal of the Association for Information Science \& Technology, vol. 66(2), hal. 354-362.

Dian, N. F., dan Artanti, Y. (2013). Pengaruh Kelompok Acuan dan Atmosfir Restoran Terhadap Keputusan Pembelian Konsumen Starbucks Coffee. Jurnal Ilmu Manajemen. Universitas Negeri Surabaya. Vol. 1(2), hal. 414-427.

Hidvégi, Anna dan Kelemen-Erdős, Anikó. (2016). “Assessing the Online Purchasing Decisions of Generation Z". FIKUSZ '16 Symposium for Young Researchers. Óbuda University. hal. 173-181

Kamila, Korina Tasya dkk. (2019). Pengaruh Online Consumer Review terhadap Keputusan Pembelian (Survei Pada Mahasiswa Universitas Brawijaya Ta 2015/2016 2018/2019 Yang Pernah Membeli Dan Menggunakan Xiaomi Smartphone). Jurnal Administrasi Bisnis. Universitas Brawijaya. Vol.7(01) hal. 202-211.

Kardon, B. (2007), They're saying nasty things. Marketing News, Vol. 41(20), hal. 30 
Ketto, Paskalis Ferdinan Bereket dan Murti, Desideria Cempaka Wijaya. (2014). Proses Pengambilan Keputusan dalam Membeli Sepatu Olahraga. Jurnal Ilmu Komunikasi. Universitas Atma Jaya Yojyakarta, hal 1-10

Kotler, Philip dan Keller, Kevin Lane. (2012). Marketing Management: $14^{\text {th }}$ Edition. New Jersey: Pearson Education.

McCrindle, Mark. (2009). The ABC of XYZ: Understanding the global generations. Bella Vista: McCrindle Research Pty.

Pramudi, R. Y. (2015). Pengaruh gaya hidup konsumtif dan kelompok referensi terhadap keputusan pembelian kosmetik lokal. Jurnal Riset Ekonomi dan Manajemen, 15(2), hal. 280-301

Ramadhan, Andre Fachrun dan Simanjuntak, Megawati. (2018). "Perilaku Pembelian Hedonis Generasi z: Promosi Pemasaran, Kelompok Acuan, Dan Konsep Diri”. Jurnal Ilmu Keluarga dan Konsumen. Institut Pertanian Bogor. Vol. 11(3) hal. 243 254.

Santoso, Giovani dan Triwijayati, Anna. (2018). "Gaya Pengambilan Keputusan Pembelian Pakaian Secara Online pada Generasi z Indonesia”. Jurnal Ilmu Keluarga dan Konsumen. Institut Pertanian Bogor. Vol. 11(3) hal. 231 - 242.

Stillman, David. dan Stillman, Jonah. (2017). Gen Z Work: How the Next Generation Is Transforming the Workplace. New York: HarperCollins Publishers.

Tapscott, Don. (2009). Grown Up Digital: How the Net Generation is Changing Your World. New York: McGraw Hill.

Thomas, M. R., Kavya, V., \& Monica, M. (2018). “Online websites cues influencing the purchase intention of generation $\mathrm{Z}$ mediated by trust". Indian Journal of Commerce \& Management Studies, 9 (1), hal. 13-23.

We are Social. (2020). Digital 2020: July Global Statshot Report. https://datareportal.com/reports/digital-2020-july-global-statshot

Wijoyo, Hadion dkk. (2020). Generasi z dan Revolusi Industri 4.0. Banyumas: CV. Pena Persada.

Yang, Jiaqin dkk. (2007). Social Reference Group Influence on Mobile Phone Purchasing Behavior: A Aross Nation Comparative study". Journal Mobile Communications. InderScience Publishers. Vol. 5(3) hal. 319-338. 